\title{
Hjerneskade hos premature målt ved 14 års alder
}

\author{
Norske forskere har påvist endringer \\ i nervefibersubstansen i hjernen hos \\ ungdommer som var sterkt premature \\ ved fødsel. Artikkelen ble kåret til årets \\ publikasjon ved St. Olavs hospital.
}

Ved hjelp av såkalt diffusjonstensor-MR visualiserte man organiseringen av hjernefibersubstansen hos barn med svært lav fødselsvekt (1). I hjernens hvite nervefibersubstans er vanndiffusjonen mye større på langs enn på tvers av nervefibrene. Dette kommer av at cellemembraner og myelinskjeden lager en barriere. Metoden kan derfor benyttes til å kartlegge arkitekturen eller organiseringen av mikrostrukturen i hvit substans.

- Vi fant at barn med fødselsvekt $<1500 \mathrm{~g}$ hadde en rekke områder i hvit substans hvor det var mer uorden, dvs. mindre ensretting av nervefibrene. Disse områdene, som bl.a. inkluderte capsula interna og capsula externa, corpus callosum og de lange assosiasjonsbanene, så normale ut på vanlig konvensjonell MR, men representerte mikroskader i hvit substans som var oppstått i perinatalperioden, sier barnelege og professorstipendiat Jon Skranes ved Norges teknisk-naturvitenskapelige universitet.

- Vi fant også at avvik i ett eller flere av disse områdene korrelerte med ulike typer kliniske funksjonsforstyrrelser og vansker påvist ved tverrfaglige unders $ø$ kelser ved 14 års alder. Dette gjaldt både motoriske,

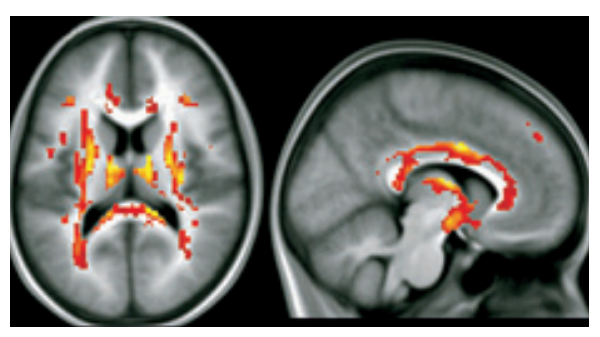

Områder (gult-rødt) i nervefibersubstansen i hjernen der barna med svært lav fødselsvekt hadde lavere FA-verdier (fractional anisotropy) enn kontrollbarna. Disse områdene inkluderte deler av de lange assosiasjonsbanene, capsula interna og externa (bildet til venstre) og corpus callosum (bildet til høyre). Illustrasjonsfoto

perseptuelle, kognitive, psykiatriske og atferdsmessige avvik, forteller han.

- Konklusjonen var at perinatal skade av hvit substans vedvarer opp i ungdomsalderen hos barn med svært lav fødselsvekt, og at dette har klinisk betydning og kan være med på å forklare den økte forekomsten av nevrologiske avvik som vi ser hos disse pasientene, sier Skranes.

\section{Geir Jacobsen}

geir.jacobsen@ntnu.no

Tidsskriftet

\section{Litteratur}

Skranes J, Vangberg T, Kulseng S et al. Clinical findings and white matter abnormalities seen on diffusion tensor imaging in adolescents with very low birth weight. Brain 2007; 130: 654-66.

\section{Løfterik vaksine mot malaria}

\section{Afrikanske barn opptil fire års alder hadde klar nytte av en nyutviklet vaksine.}

Malaria forårsaker $8 \%$ av barnedødeligheten på verdensbasis. Utvikling av en effektiv vaksine har lenge vært høyt prioritert, uten at man har lyktes med å fremskaffe noen. Men nylig viste resultatene fra en stort anlagt intervensjonsstudie i Kenya og Tanzania at malariavaksinen RTS,S/AS01E var klinisk og statistisk signifikant bedre enn kontrollvaksinen (1).

- Av de vaksinene som har vært utprøvd til nå, synes det som om denne er kommet lengst - den virker derfor mest lovende. Men det er fortsatt langt frem før vaksinen kan tas i bruk i større omfang, sier barnelege Arne Kristian Myhre ved St. Olavs hospital. - Studien er svært interessant fordi man kan se konturene av et forebyggende tiltak med spesielt stor effekt på barne- helsen. I dag er hovedstrategiene bruk av insekticidimpregnerte myggnett og medikamenter som profylakse eller ved klinisk sykdom. Et hovedproblem ved bruken av medikamenter er den svært raske resistensutviklingen. En vaksine vil også av den grunn være en kjærkommen nyvinning. Fattigdom, sykdom og miljø er utfordringer enten vi bor i Norge eller i Kenya. Med økt oppmerksomhet på global oppvarming er det dessuten grunn til å minne om at malaria også fantes i Norge på 1800-tallet, og at andre varmekrevende sykdommer som Lyme-borreliose er på fremmarsj, påpeker Myhre.

\section{Geir Jacobsen}

geir.jacobsen@ntnu.no

Tidsskriftet

\section{Litteratur}

Bejon P, Lusingu J, Olotu A et al. Efficacy of RTS,S/ AS01E vaccine against malaria in children 5 to 17 months of age. N Engl J Med 2008; 359: 2521-32.
Mikro-RNA regulerer hypertrofisk vekst av hjertemuskel Mikro-RNA er små, konserverte RNAmolekyler som deltar i reguleringen av genuttrykk. De er involvert i flere biologiske prosesser, f.eks. celleproliferasjon og apoptose. Nye forskningsresultater tyder nå på at mikro-RNA spiller en rolle i hypertrofi av hjertet (Nat Med 2007; 13: 613-8).

Forskningsgruppen fant at uttrykket av spesifikke typer mikro-RNA er redusert i hypertrofisk hjertevev fra både mus og menneske. Videre benyttet de flere musemodeller og fant at nedregulering av disse induserte hypertrofi av hjertet. Den molekylære mekanismen bak hypertrofien ble avdekket, og forskerne konkluderer med at dette kan åpne for nye terapeutiske angrepspunkter.

\section{Miljøtoksiner i tobakk påvirker fosterets testikler}

Tidligere studier har vist at sønner av kvinner som røykte under svangerskapet, hadde nedsatt spermieproduksjonen. Tobakk inneholder miljøgiftene polysykliske aromatiske hydrokarboner, som binder til arylhydrokarbonreseptoren (AHR). Nå har skotske forskere undersøkt om denne reseptoren finnes i testikkel hos foster (Hum Reprod 2007; 22: 2912-8).

Lokalisering av AHR i testikkelen ble undersøkt ved immunohistokjemiske metoder. AHR ble påvist i første og annet trimester, men kun i kjønnscellene, forløperne til spermiene. Ved å dyrke testiklene i nærvær av en AHR-ligand som finnes i sigarettrøyk, ble det observert apoptose av kjønnsceller. Dette kan være en av mekanismene som ligger bak den skadelige effekten av morens røyking på sønnens sædproduksjon.

\section{Meslinger og vaksinedekning}

En studie av meslinger og vaksinedekning i 32 europeiske land har vist at det var mer enn 12000 tilfeller av sykdommen i 2006-07, mesteparten hos barn som ikke var vaksinert (Lancet 2009, doi: 10.1016/ S0140-6736(08)61849-8). 85\% av tilfellene fantes i Romania, Tyskland, Storbritannia, Sveits og Italia - land med suboptimal vaksinedekning.

Verdens helseorganisasjon anbefaler minimum $95 \%$ vaksinedekning med to doser for å eliminere meslinger. I disse fem landene var det en vaksinedekning på $70-90 \%$, med store regionale variasjoner. I land der det ikke var noen tilfeller av meslinger, hadde det vært en vaksinedekning på over $95 \%$ i lengre perioder. Bedre vaksinedekning i visse land er nødvendig for å nå målet om eliminering av meslinger innen 2010, konkluderer forfatterne. 